\title{
Respiration rate of Golden papaya stored under refrigeration and with different controlled atmospheres
}

\author{
Derliane Ribeiro Martins, Nayara Cantarino Barbosa, Eder Dutra de Resende*
}

Northern Rio de Janeiro State University/Food Technology Lab., Av. Alberto Lamego, 2000 - 28013-602 - Campos dos Goytacazes, RJ - Brazil.

*Corresponding author <eresende@uenf.br>

Edited by: Francesco Montemurro

Received October 09, 2013

Accepted March 21, 2014

\begin{abstract}
Knowledge of the respiration rate during the storage is important in the evaluation of the post-harvest tools that preserve fruit quality, and also for the provision of information for the development of new packages. This work aimed to evaluate the respiration rate of 'Golden' Carica papaya stored under refrigeration and controlled atmosphere conditions. The fruit was kept at 13 ${ }^{\circ} \mathrm{C}$ in controlled atmospheres comprising three levels of $\mathrm{O}_{2}(20.8 \%, 6 \%, 3 \%)$ with a minimum level of $\mathrm{CO}_{2}(0.1 \%)$; and three levels of $\mathrm{CO}_{2}(0.1 \%, 6 \%, 12 \%)$ with the lowest level of $\mathrm{O}_{2}(3$ $\%)$. Measurements were taken at intervals of 5 days during the 30 days of storage. The mass loss and the peel color of the fruits were identified at the end of the storage period. The fruit maintained under 'normal' atmosphere conditions $\left(20.8 \% \mathrm{O}_{2}\right.$ and $\left.0.1 \% \mathrm{CO}_{2}\right)$ increased its respiration rate after the $10^{\text {th }}$ day, reaching after 30 days 4.3 times the initial value. After 30 days in $3 \% \mathrm{O}_{2}$, the respiration rate was 2.9 times less than in the normal atmosphere. The decrease in respiration rate minimized the mass loss in fruit stored at $3 \% \mathrm{O}_{2}$, but it was unaffected by increasing levels of $\mathrm{CO}_{2}$.
\end{abstract}

Keywords: Carica papaya, cold storage, modified atmosphere, ripening, mass loss

\section{Introduction}

Papaya fruit (Carica papaya L.) has a restricted storage time due to rapid pulp softening and fungal growth. It is a climacteric fruit whose respiratory rate and ethylene production increase considerably after harvest. In tropical climates, papaya loses its quality rapidly and its storage is limited to seven days (Paull et al., 1997). During the storage of papaya, biochemical reactions promote changes in respiratory rate, mass loss, chlorophyll breakdown, production of carotenoids in the skin, and loss of firmness (Abou Aziz et al., 1975).

The respiration rate is more affected by storage temperature, $\mathrm{O}_{2}, \mathrm{CO}_{2}$ and ethylene levels, than by the influence of the ripening process of fruits (Mahajan and Goswani, 2001). The lowering of $\mathrm{O}_{2}$ levels interferes with the oxidation reactions in the respiratory chain and minimizes or inhibits the synthesis of ethylene. The increase in $\mathrm{CO}_{2}$ levels interferes with the activity of Krebs cycle enzymes, and reduce fruit metabolism (Kader, 1987). Under limited oxygen conditions, the enzymes pyruvate decarboxylase and alcohol dehydrogenase metabolize pyruvate to produce ethanol and $\mathrm{CO}_{2}$ (Taiz and Zeiger, 2010).

Generally, fruits stored under aerobic conditions show a respiratory quotient (RQ) between 0.7 and 1.3 depending upon the substrate being used predominantly in the biochemical process (Kader and Ben-Yehoshua, 2000). In contrast, under anaerobic conditions there is a higher RQ. The respiratory quotient is an indicative parameter of the activation of anaerobic pathways (Saquet and Streif, 2002).

Golden papaya may present quality problems when kept in $\mathrm{O}_{2}$ concentrations below $3 \%$. An increase in $\mathrm{CO}_{2}$ concentration to $15 \%$ preserves chemical com- ponents in the pulp, but adequate conditions for acceptance of the product requires an atmosphere of $3 \% \mathrm{O}_{2}$ and $6 \% \mathrm{CO}_{2}$ (Martins and Resende, 2013).

The measurement of the respiration rate is necessary for an understanding of the behavior of fruit stored under controlled or modified atmosphere conditions, thereby providing information for the selection of appropriate packaging for the fruit. We found no studies in the literature on the respiration of papayas under different controlled atmosphere conditions. We determined the respiration rate of Golden papaya kept under refrigeration at $13{ }^{\circ} \mathrm{C}$ in concentrations of $\mathrm{O}_{2}$ decreasing down to the minimum level of $3 \%$, and increasing $\mathrm{CO}_{2}$ levels up to the limit of $12 \%$. The product was also evaluated with regard to mass loss and changes in peel color.

\section{Materials and Methods}

Golden papayas were selected in a packing house located in a commercial orchard in Linhares (state of Espirito Santo, Brazil, $19.3908^{\circ}$ S, $\left.40.0719^{\circ} \mathrm{W}\right)$. Fruits were harvested with approximately $15-25 \%$ of yellow peel color and an average weight of $350 \mathrm{~g}$, washed in chlorinated water $\left(0.1 \mathrm{~mL} \mathrm{~L}^{-1}\right.$ active chlorine) and treated in a hydrothermal bath $\left(48^{\circ} \mathrm{C} / 20 \mathrm{~min}\right)$ followed by immersion in a fungicide (Prochloraz) solution for $2 \mathrm{~min}$. The fruits selected were packed in corrugated cardboard boxes, stored at $12{ }^{\circ} \mathrm{C}$ and transported under refrigeration to the laboratory where the experiments were conducted, beginning $36 \mathrm{~h}$ after harvest.

The papayas were stored in small chambers containing perforated shelves used to support the fruits. All these materials had been previously cleaned with hypochlorite solution (0.2 $\mathrm{mL} \mathrm{L}^{-1}$ of active chlorine) and sterilized for $48 \mathrm{~h}$ by a gas-producing mixture $10.5 \mathrm{~L}$ of 50 
$\%$ formaldehyde, $0.5 \mathrm{~L}$ of water and $250 \mathrm{~g}$ of potassium permanganate). Before storage, the fruits were selected, weighed and evaluated for peel color using a Hunter colorimeter.

The empty air space inside the chambers was calculated by the difference between the total volume of the chamber $(102.85 \mathrm{~L})$, the volume of the shelf $(0.65 \mathrm{~L})$ and the volume of fruit assessed after the determination of mass and density of a significant sample of papayas of the same standard format and maturation stage. Density was obtained by calculating the correlation between fruit mass and volume of distilled water displaced by immersing the fruit in a calibrated beaker.

Thirty fruits were stored in each chamber and kept under refrigeration at $13{ }^{\circ} \mathrm{C}$ and 85-95 \% RH (CLIMASUL, Brazil). The homogeneity of the atmospheres was maintained by a small fan positioned in the upper side of the chambers. The gas levels were set at decreasing $\mathrm{O}_{2}$ levels (normal atmosphere or $20.8 \%, 6 \%$ and 3 $\%$ ) with $0.1 \% \mathrm{CO}_{2}$ and also at the lower $\mathrm{O}_{2}$ level (3\%) with increasing $\mathrm{CO}_{2}$ level $(0.1 \%, 6 \%$ and $12 \%)$. These gas concentrations were defined according to Martins and Resende (2013) who suggested the best conditions for the storage of Golden papaya.

The atmospheres were set up by flushing with $\mathrm{N}_{2}$ and $\mathrm{CO}_{2}$ at the beginning of the storage period until the required gas levels were obtained. The $\mathrm{O}_{2}$ and $\mathrm{CO}_{2}$ concentrations were controlled by flushing with nitrogen gas and adding $\mathrm{CO}_{2}$. The levels selected were kept constant by scrubbing off excess $\mathrm{CO}_{2}$ produced by respiration and adding air for $\mathrm{O}_{2}$. Gas concentrations were monitored daily using computerized analyzers with paramagnetic $\left(\mathrm{O}_{2}\right)$ and infrared detection $\left(\mathrm{CO}_{2}\right)$. Ethylene adsorption was achieved by pumping the air through a permanganate sorption column.

Mass loss was measured after 30 days of storage under controlled atmosphere conditions using an electronic balance, with measurements normalized to $100 \mathrm{~g}$ of fruit. Peel color was recorded with a Hunter colorimeter with measurements taken at two equidistant points of the equatorial portion; on the side of the fruits that were exposed and not exposed to sunlight. The results were expressed by the Hunter L, a, and b parameters.

Respiration rate was assessed every five days, taking direct measurements of the concentrations of $\mathrm{O}_{2}$ (paramagnetic sensor) and $\mathrm{CO}_{2}$ (infrared sensor) after suction of samples of air from the chambers. During the measurements, the control parameters of injection of $\mathrm{O}_{2}$ and $\mathrm{N}_{2}$, as well as $\mathrm{CO}_{2}$ and ethylene adsorption were disabled for a period of $5 \mathrm{~h}$, allowing for five measurements of gas concentrations. The linear data fitting allowed for the determination of respiration rate in $\% \mathrm{~kg}^{-1} \mathrm{~h}^{-1}$. These values were corrected on the basis of the gas volume in the empty space of the chamber to determine the rate of respiration in $\mathrm{mL} \mathrm{kg} \mathrm{k}^{-1} \mathrm{~h}^{-1}$, according to Equation 1as follows:

$$
R_{\text {resp }}=\frac{\Delta_{\%}}{\Delta_{t}} \times \frac{V_{e v}}{100} \times \frac{1}{m}
$$

in which $R_{\text {resp }}$ is the rate of $\mathrm{O}_{2}$ consumption or $\mathrm{CO}_{2}$ production $\left(\mathrm{mL} \mathrm{kg}^{-1} \mathrm{~h}^{-1}\right), \Delta_{\%}$ represents the variation of the $\mathrm{O}_{2}$ concentration or $\mathrm{CO}_{2}$ over time $(\%), \Delta_{t}$ is the time interval used for gas concentration (h) measurements, $m$ is the mass of fruits inside the chamber $(\mathrm{kg})$ and $V_{e v}$ is the volume of void space in the chamber $(\mathrm{mL})$.

The experimental design was completely randomized for each treatment, comprising 30 fruits per treatment with two replicates. The results of mass loss and fruit color were interpreted by simple statistical analyses, and the data were compared by confidence intervals applying Student's t-test $(p<0.05)$. The samples were dimensioned for an infinite population of papaya fruits considering the probability of $p \leq 0.05$ and $10 \%$ deviation around the sampling media. The respiration rate results were interpreted by regression models of the data and their coefficients of determination using the statistical SAEG software (SAEG, 2007, version 9.1).

\section{Results and Discussion}

\section{Evaluation of peel color and fruit mass loss}

The fruit prior to storage had a lower luminosity (Hunter L), a lower yellowness index (Hunter b), and negative values of Hunter a (typical of a green color) (Figure 1). The values of Hunter L and Hunter b on the fruit side exposed to the sun were smaller than on the unexposed side (Figure 1A and $1 \mathrm{~B}$ ). In the analysis of the Hunter a parameter, a trend for the lower values on the fruit side exposed to the sun emerges (Figure 1C). These results are consistent with those described by Vitorazi et al. (2011) for the variation of the peel color of Golden papaya as affected by exposure to the sun during its ontogeny in the plant.

Fruits stored for 30 days under controlled atmosphere conditions with minimum levels of $\mathrm{CO}_{2}(0.1 \%)$ had color patterns typical of ripe fruits when kept in an atmosphere of $20.8 \% \mathrm{O}_{2}$ or $6 \% \mathrm{O}_{2}$, with average values of $65.63( \pm 1.18)$ and $35.11( \pm 0.75)$ for the Hunter $L$ and Hunter $\mathrm{b}$ parameters respectively (Figure $1 \mathrm{~A}$ and 1B). This is consistent with the color scale of Golden papaya in the ripe stage, as described by Oliveira et al. (2002), with average values of Hunter L equal to 64.20 $( \pm 2.04)$ and Hunter $b$ equal to $32.19( \pm 1.22)$. Ripening is retarded in an atmosphere containing the lower level of $\mathrm{O}_{2}(3 \%)$, even in an atmosphere containing 0.1 $\% \mathrm{CO}_{2}$, as indicated by small values of Hunter a (Figure 1C). The increase in $\mathrm{CO}_{2}$ level in chambers with $3 \% \mathrm{O}_{2}$ also promotes a slowing down in the ripening process. Fruits stored in an atmosphere with $3 \% \mathrm{O}_{2}$ and $12 \%$ $\mathrm{CO}_{2}$ presented the smaller values of Hunter b (Figure 1B) and Hunter a (Figure 1C).

Mass loss was reduced markedly when the $\mathrm{O}_{2}$ level was set at the lower value in atmospheres with the minimum level of $\mathrm{CO}_{2}(0.1 \%)$ (Figure 2). However, a trend of reduction of mass loss was detected when the $\mathrm{O}_{2}$ concentration was changed from $20.8 \%$ to $6 \% \mathrm{O}_{2}$, with average values of $4.70 \%$ and $4.16 \%$, respectively. 

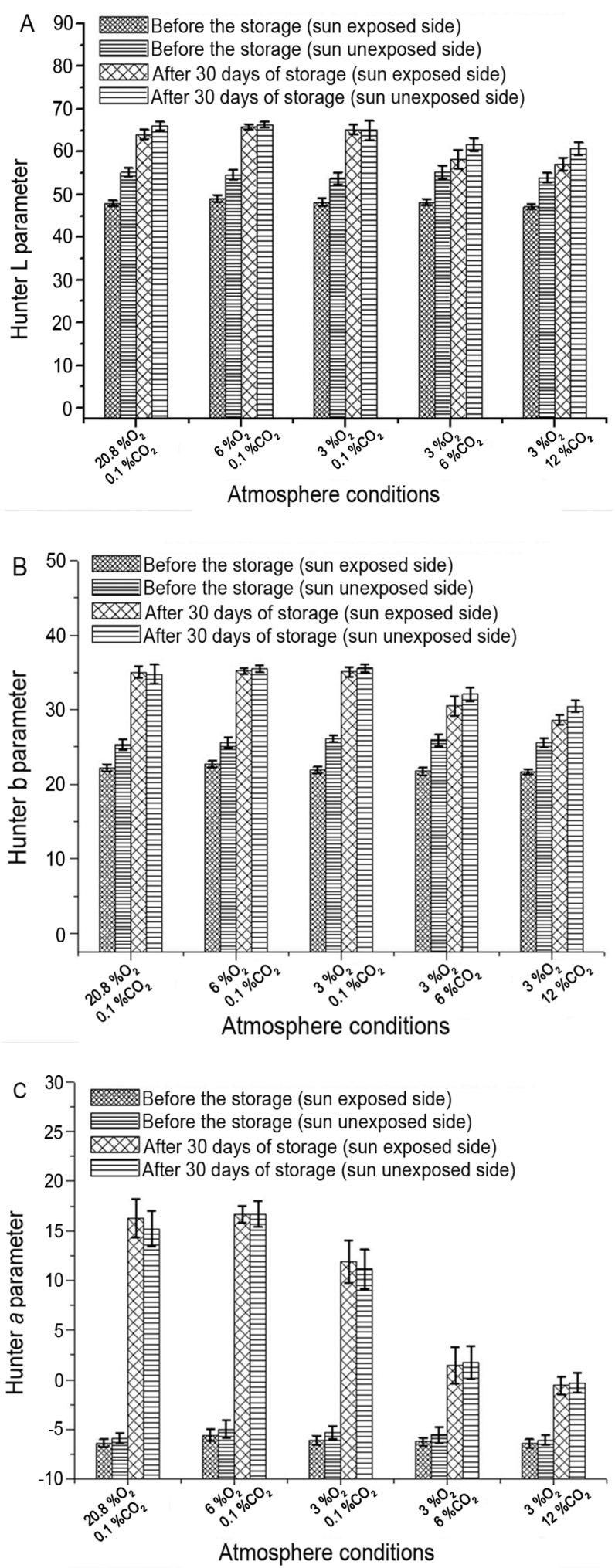

Figure 1 - Measurements of Hunter L (A), Hunter b (B) and Hunter a (C) on the peel of Golden papaya kept under controlled atmosphere conditions during 30 days of storage at $13{ }^{\circ} \mathrm{C}$ and $85-95 \%$ relative humidity. Vertical bars indicate confidence intervals at $p \leq 0.05$.

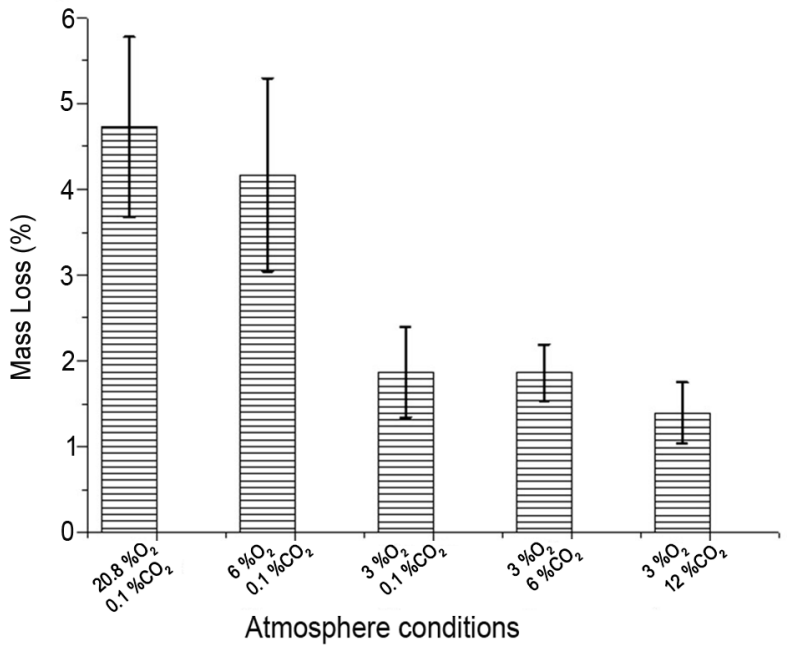

Figure 2 - Average of mass loss of Golden papaya kept under controlled atmosphere conditions during 30 days of storage at 13 ${ }^{\circ} \mathrm{C}$ and $85-95 \%$ relative humidity. Vertical bars indicate confidence intervals at $p \leq 0.05$.

A reduction of $64 \%(p<0.05)$ in mass loss occurred when the atmosphere was changed from $20.8 \%$ to the minimum concentration of $\mathrm{O}_{2}(3 \%)$ and, under these conditions; increased $\mathrm{CO}_{2}$ concentrations did not affect mass loss, with average values of $1.71 \%$ (Figure 2).

Mass loss in Golden papaya reached $9.17 \%$ when stored at $10{ }^{\circ} \mathrm{C}$ and $90 \% \mathrm{RH}$ for a period of 32 days under ambient conditions (Pinto et al., 2006). Mass loss is directly related to the loss of water, with loss of quality associated with worse appearance and texture. In Golden papaya, mass loss follows zero-order kinetics at a constant rate during storage due to the resistance of the peel to water permeability (Pinto et al., 2006).

\section{Respiration rate}

Golden papaya kept in different controlled atmosphere conditions for 30 days at $13{ }^{\circ} \mathrm{C}$ increased its respiration rate during the storage period, characterizing its climacteric behavior. During the first 10 days of storage, the fruits kept in different atmospheres showed low values of respiration rate, typical of pre-climacteric behavior. However, this respiration rate progressively increased in fruits kept in an atmosphere with $20.8 \%$ $\mathrm{O}_{2}$ and $0.1 \% \mathrm{CO}_{2}$, reaching $\mathrm{CO}_{2}$ production of $33.18 \mathrm{~mL}$ $\mathrm{kg}^{-1} \mathrm{~h}^{-1}$, representing an increase of $76.6 \%$ in the respiration rate, approximately 4.3 times the initial value, after 30 days of storage (Figure 3). The reduction in $\mathrm{O}_{2}$ concentration to the limit of $3 \%$ promoted a decrease in respiration rate in atmospheres with the minimum level of $\mathrm{CO}_{2}(0.1 \%)$. In this case, the respiration rate was reduced by approximately $66 \%$ (2.94 times) of the value in a normal atmosphere, after 30 days of storage (Figure 3).

In an atmosphere with the lower $\mathrm{O}_{2}$ level $(3 \%)$ an increase in respiration rate was also observed through the 30 days of storage under refrigeration. Even in an 
atmosphere with the higher $\mathrm{CO}_{2}$ level $(12 \%)$, the $\mathrm{CO}_{2}$ production reached $11.29 \mathrm{~mL} \mathrm{~kg}^{-1} \mathrm{~h}^{-1}$, representing an increase of $53 \%$ in relation to the value at the beginning of storage (Figure 3). In this way, even under conditions of cold storage, the use of atmospheres with higher levels of $\mathrm{O}_{2}$ allows for increases in the respiration rate and consequently, a faster fruit ripening, as indicated by higher values of the Hunter peel color parameters at the end of the storage period (Figure 1). On the other hand, reducing the $\mathrm{O}_{2}$ level to $3 \%$ produces a lower respiration rate, providing a slower ripening and with the possibility of a significant increase in the storage time.

The measurements of $\mathrm{O}_{2}$ consumption showed similar behavior to that observed for the rate of $\mathrm{CO}_{2}$ release, with values of the same magnitude under different controlled atmospheric conditions. The decrease in $\mathrm{O}_{2}$ consumption is highlighted when the level of $\mathrm{O}_{2}$ in the chambers is changed from $20.8 \%$ to $3 \% \mathrm{O}_{2}$, under the minimum level of $\mathrm{CO}_{2}(0.1 \%)$, especially at the end of storage (Figure 4).

Under conditions of low $\mathrm{O}_{2}$ content $(3 \%)$, increasing the $\mathrm{CO}_{2}$ level in the chambers (up to $12 \%$ ) produces only a small decrease in the rate of $\mathrm{O}_{2}$ consumption. This means that, under conditions of refrigeration at 13 ${ }^{\circ} \mathrm{C}$ and low content of $\mathrm{O}_{2}$, the use of atmospheres containing high concentrations of $\mathrm{CO}_{2}$ (up to $12 \%$ ) had a negligible effect on reducing the respiration rate of papaya. However, in an atmosphere containing $3 \% \mathrm{O}_{2}$ and 12 $\% \mathrm{CO}_{2}, \mathrm{O}_{2}$ consumption reached its lowest value at the end of 30 days, when compared to other treatments in controlled atmospheres. This result explains the slower ripening process of the fruits, as indicated by the smaller value of the Hunter a parameter (Figure 1C).

In Sunrise papaya stored in ambient conditions there is an increase of $\mathrm{CO}_{2}$ production after the 4th day after harvest, varying from $5 \mathrm{~mL} \mathrm{~kg}^{-1} \mathrm{~h}^{-1}$ to approxi-

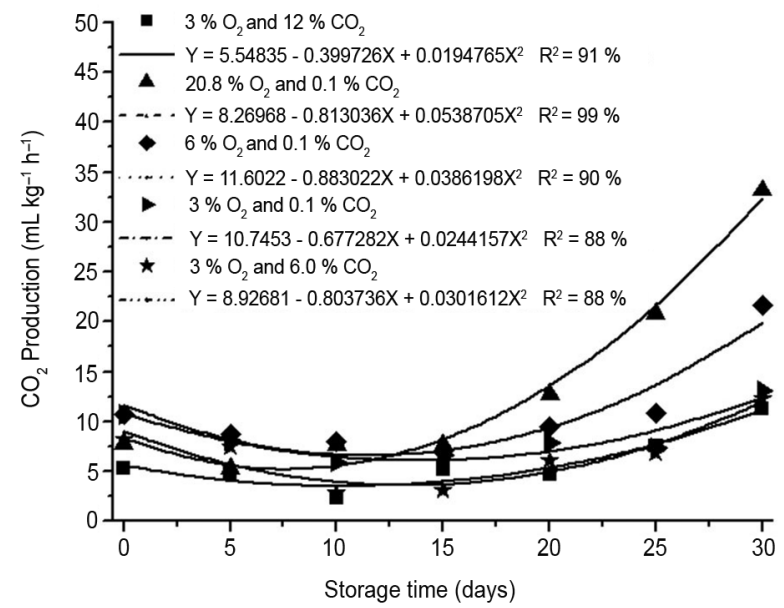

Figure 3 - Production of $\mathrm{CO}_{2}$ during the storage of Golden papaya at $13{ }^{\circ} \mathrm{C}$ and $85-95 \%$ relative humidity for 30 days under conditions of controlled atmosphere with ethylene adsorption. mately $45 \mathrm{~mL} \mathrm{~kg}^{-1} \mathrm{~h}^{-1}$ by the $10^{\text {th }}$ day of storage (Paull and Chen, 1983). Papaya cultivars, however, have quite distinct respiratory patterns, and the Sunrise variety reaches a maximum respiratory rate on the $4^{\text {th }}$ day of storage under ambient conditions (approximately 50 $\mathrm{mL} \mathrm{kg}^{-1} \mathrm{~h}^{-1}$ ), while other cultivars (RL-1-3 and RL-1-120) show an increase in respiration only at the $10^{\text {th }}$ day after harvest, reaching levels around $30 \mathrm{~mL} \mathrm{~kg}{ }^{-1} \mathrm{~h}^{-1}$ (Zhang and Paull, 1990).

The highest rate of $\mathrm{CO}_{2}$ production in Golden papaya (approximately $60 \mathrm{mg} \mathrm{kg}^{-1} \mathrm{~h}^{-1}$ ) occurs on the $4^{\text {th }}$ day of storage at ambient conditions (Fabi et al., 2007). In fact, both the Golden papaya and the Sunrise Solo present the highest rate of $\mathrm{CO}_{2}$ emission at the fourth day of storage (approximately $25 \mathrm{mg} \mathrm{kg}^{-1} \mathrm{~h}^{-1}$ ) under ambient conditions, but the respiratory rate reaches its highest level during the senescence stage (Fonseca et al., 2006). Nevertheless, Golden papaya kept in ambient conditions shows a small decrease in the respiration rate immediately after harvest, but from the $3^{\text {rd }}$ day on there is a trend of increasing $\mathrm{CO}_{2}$ production, mainly in fruits harvested in the early stages of ripening, reaching $31 \mathrm{~mL} \mathrm{~kg}^{-1} \mathrm{~h}^{-1}$ after the ripening (Bron and Jacomino, 2006).

Fabi et al. (2007) observed that the $\mathrm{CO}_{2}$ production of Golden papaya kept at ambient temperature $\left(25^{\circ} \mathrm{C}\right)$ reached $60 \mathrm{mg} \mathrm{kg}^{-1} \mathrm{~h}^{-1}$ by the $4^{\text {th }}$ day of storage. In the present experiment, the respiration rate of fruits kept under refrigeration and ambient atmosphere conditions $\left(20.8 \% \mathrm{O}_{2}\right.$ and $\left.0.1 \% \mathrm{CO}_{2}\right)$ starts to increase on the $10^{\text {th }}$ day of storage, with $\mathrm{CO}_{2}$ production varying from 7.62 $\mathrm{mL} \mathrm{kg}{ }^{-1} \mathrm{~h}^{-1}$ to $33.18 \mathrm{~mL} \mathrm{~kg}^{-1} \mathrm{~h}^{-1}$, by the $30^{\text {th }}$ day. This means that the cold storage is responsible for slowing the ripening process by reducing the magnitude of the respiration rate as well as increasing the time required to start the climacteric respiration.

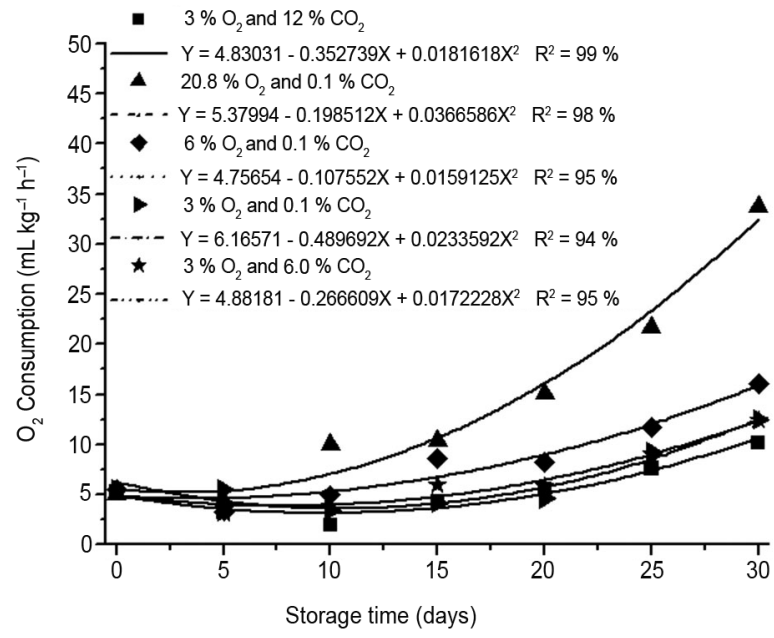

Figure 4 - Consumption of $\mathrm{O}_{2}$ during the storage of Golden papaya at $13^{\circ} \mathrm{C}$ and $85-95 \%$ relative humidity for 30 days under conditions of controlled atmosphere with ethylene adsorption. 
The reduction in the oxygen level has a notable influence on decreasing the respiration rate of cultivars of apple (Malus domestica) stored at $1{ }^{\circ} \mathrm{C}$, with a much stronger effect as compared with an increasing level of $\mathrm{CO}_{2}$ in the storage chamber. The rate of $\mathrm{CO}_{2}$ production is decreased more prominently in atmospheres with $\mathrm{O}_{2}$ concentrations below $5 \%$, and most cultivars show their lowest respiration rate at concentrations of $1.5 \% \mathrm{O}_{2}$. In atmospheres with oxygen levels below this concentration, an increase in respiration rate is observed due to anaerobic respiration (Saquet and Streif, 2002).

The respiration rate of banana (Musa spp.) is less influenced by increasing levels of $\mathrm{CO}_{2}$ in storage (Heydari et al., 2010). In the same way, the reduction of the respiration rate of mango, orange and green banana is little influenced by the $\mathrm{CO}_{2}$ level. This is attributed to the fact that higher levels of $\mathrm{CO}_{2}$ can act as competitive inhibitors of the $\mathrm{O}_{2}$ intake for the enzymatic reaction, both leading to a reduction in the respiration rate as well as in energy supply for the physiological process (Kole and Prasad, 1994). The $\mathrm{CO}_{2}$ concentration can reduce or inhibit the synthesis of ethylene, depending on the gas level in tissue, time of exposure, storage temperature and variety of the fruit (Rothan and Nicolas, 1994; Mathooko, 1996)

\section{Conclusions}

Golden papaya stored under refrigeration $\left(13^{\circ} \mathrm{C}\right)$ in a 'normal' atmosphere increases its respiration rate after the $10^{\text {th }}$ day of storage. In an atmosphere with the minimum level of $\mathrm{O}_{2}$, the respiration rate is reduced to approximately $66 \%$ (2.94 times) of the value in normal atmosphere, after 30 days of storage. The $\mathrm{CO}_{2}$ levels had a very small influence on reducing the respiration rate of papaya fruits stored under refrigeration in an atmosphere of $3 \% \mathrm{O}_{2}$. The decrease in the respiration rate minimized the mass loss in fruits stored at $3 \% \mathrm{O}_{2}$, but it was unaffected by increased levels of $\mathrm{CO}_{2}$. The changes in peel color were influenced by decreasing levels of $\mathrm{O}_{2}$ as well as increasing levels of $\mathrm{CO}_{2}$.

\section{Acknowledgements}

The authors gratefully acknowledge FINEP (Brazil) and FAPERJ (Brazil) for financial grants, and CNPq and CAPES (Brazil) for the research grants, and also the Caliman Agrícola Company for the use of its facilities.

\section{References}

Abou Aziz, A.B.; El-Nabawy, S.M.; Zaki, H.A. 1975. Effect of different temperatures on the storage of papaya fruits and respirational activity during storage. Scientia Horticulturae 3: 173-177.

Bron, I.U.; Jacomino, A.P. 2006. Ripening and quality of 'Golden' papaya fruit harvested at different maturity stages. Brazilian Journal of Plant Physiology 18: 389-396.
Fabi, J.P.; Cordenunsi, B.R.; Barreto, G.P.M.; Mercadante, A.Z.; Lajolo, F.M.; Nascimento, J.R.O. 2007. Papaya fruit ripening: response to ethylene and 1-Methylcyclopropene (1-MCP). Journal of Agricultural and Food Chemistry 55: 6118-6123.

Fonseca, M.J.O.; Leal, N.R.; Cenci, S.A.; Cecon, P.R.; BressanSmith, R.E.; Soares, A.G. 2006. Emission of ethylene and $\mathrm{CO}_{2}$ in 'Sunrise Solo' and 'Golden' papaya. Revista Brasileira de Fruticultura 28: 322-324 (in Portuguese, with abstract in English).

Heydari, A.; Shayesteh, K.; Eghbalifam, N.; Bordbar, H.; Falahatpisheh, S. 2010. Studies on the respiration rate of banana based on enzyme kinetics. International Journal of Agriculture and Biology 12: 145-149.

Kader, A.A. 1987. Respiration and gas exchange of vegetables. In: Weichmann, J (Ed.), Postharvest Physiology of Vegetables, pp: 25-43, Marcel Dekker Inc., New York.

Kader, A.A.; Ben-Yehoshua, S. 2000. Effects of super atmospheric oxygen levels on postharvest physiology and quality of fresh fruits and vegetables. Postharvest Biology and Technology 20: 1-13.

Kole, N.K.; Prasad, S. 1994. Respiration rate and heat of respiration of some fruits under controlled atmosphere conditions. International Journal of Refrigeration 17: 199-204.

Mahajan, P.V.; Goswani, T.K. 2001. Enzyme kinetics based modeling of respiration rate of apple. Journal of Agricultural Engineering Research 79: 399-406.

Martins, D.R.; Resende, E.D. 2013. Quality of Golden papaya stored under controlled atmosphere conditions. Food Science and Technology International 19: 473-481.

Mathooko, F.M. 1996. Regulation of ethylene biosynthesis in higher plants by carbon dioxide. Postharvest Biology and Technology 7 : $1-26$.

Oliveira, M.A.B.; Vianni, R.; Souza, G.; Araújo, T.M.R. 2002. Characterization of maturation stage of 'Golden' papaya in related color. Revista Brasileira de Fruticultura 24: 559-561 (in Portuguese, with abstract in English).

Paull, R.E.; Chen, N.J. 1983. Postharvest variation in cell walldegrading enzymes of papaya. Plant Physiology 72: 382-385.

Paull, R.E.; Nishijima, W.; Reyes, M.; Cavaletto, C. 1997. Postharvest handling and losses during marketing of papaya (Carica papaya L.). Postharvest Biology and Technology 11: 165-179.

Pinto, L.K.A.; Martins, M.L.L.; Resende, E.D.; Almeida, R.F.; Vitorazi, L.; Pereira, S.M.F. 2006. Influence of a modified atmosphere by plastic film on the quality of papaya fruit stored in a refrigerator. Ciência e Tecnologia de Alimentos 26: 444-451 (in Portuguese, with abstract in English).

Rothan, C.; Nicolas, J. 1994. High $\mathrm{CO}_{2}$ levels reduce ethylene production in kiwifruit. Physiologia Plantarum 92: 1-8

Saquet, A.A.; Streif, J. 2002. Respiration and ethylene production by apples stored in different oxygen concentrations. Revista Brasileira de Agrociência 8: 71-75 (in Portuguese, with abstract in English).

Taiz, L.; Zeiger, E. 2010. Plant Physiology. 5ed. Sinauer, Sunderland, MA, USA.

Vitorazi, L.; Resende, E.D.; Martins, D.R.; Thiébaut, J.T.L. 2011. Sampling dimension for the postharvest quality characterization of papaya. Revista Brasileira de Armazenamento 36: 64-71 (in Portuguese, with abstract in English).

Zhang, L.X.; Paull, R.E. 1990. Ripening behavior of papaya genotypes. HortScience 25: 454-455. 